\title{
Construction Strategy Exploration of College English Listening and Speaking Course Under the Network Environment
}

\author{
Libin Wang, \\ Hebe Institute of Engineering and Technology, Shijiazhuang, Hebei, China
}

\begin{abstract}
In order to make college students better adapt to modern social need, improving college students' English comprehensive ability has become the top priority of the current college English teaching. However, many problems still exist in the process of actual college English listening and speaking teaching. This paper mainly discusses the existing problems of college English listening teaching, and then puts forward college English listening and speaking construction strategy under the network environment.
\end{abstract}

Key words: College English; Curriculum construction; Classroom teaching; Listening and teaching courses

\section{INTRODUCTION}

Under the background of the current ingrained exam-oriented education, most of the students ignored the learning and accumulation of English listening and speaking skills on ideology, leading to the low level of students' listening and speaking. During the period of university, as English grades link up with diploma, a lot of students passively learn English.

\section{Current Existing Problems in College English Listening and Speaking Teaching}

\subsection{Poor English Environment, Listening More and Speaking Less}

In the process of college English listening and speaking teaching, listening more and speaking less phenomenon exists Through investigation and analysis, the cause of this phenomenon mainly has two aspects: for students, when listening to materials with low difficulty, a lot of students answer the teacher's questions less seriously; When faced with difficult material, most students take the attitude of silence. This passive English learning process caused serious division of speaking and listening, thus fails to achieve the mutual influence of English listening and speaking and the study effect of listening promotes speaking and saying practices listening. For teachers, when students can't express what they are trying to say very well, teachers can't take the right approach to timely help students solve the difficulties encountered in the course of speaking. Therefore, in preparation of lessons, teachers should have a comprehensive consideration and take a gradual approach to help students better understand the information expressed in the English listening materials.

2.2 Not Enough Knowledge About the Importance of English, Lack of Interest

A psychologist once said, interest is important dynamic to learn a good course. In the process of English listening and speaking teaching, some students interested in English act initiatively with a good mood, and the effect are ideal as well; But there are still some students who think that English is not much use, and even think that learning English is a waste of time. Because the students didn't realize the importance of English and lack interest and motivation, the phenomenon of passive learning often appears in the learning process. In the long run, it leads to bad English classroom teaching effect and language learning atmosphere and low efficiency of classroom teaching.

\subsection{Unscientific Teaching Design, Bad Teaching} Effect.

In the process of English listening and teaching, teaching design plays a very important role of which scientific and reasonable college English listening and speaking teaching courses should mainly includes several aspects: The first one is to confirm clear teaching content and target; The second is to reasonably design key and difficult teaching point; The third is the multiple 
teaching methods; The fourth is to implement effective teaching methods. But in the process of practical English listening and speaking teaching, because many teachers lack experience in teaching and classroom organization ability, they are unable to design a more practical teaching method in curriculum design process, meanwhile, teaching also lacks vitality and vigor, therefore,cannot achieve the expected teaching effect.

\section{Construction Strategy of College English Listening} and Speaking Course Under the Network Environment

\subsection{Improve Students' Understanding of English,} Stimulate Interest in Learning English

In the teaching process, students are learning subject, thus, to improve the teaching effect, it should start from students. Therefore, under the network environment, technology of multimedia teaching should better feed into the process of college English listening and speaking teaching combining text, sound, image together to form a better English learning atmosphere. Through the development of the students' non-intelligence factors, students' interest in learning English can be stimulated which get twice the result with half the effort in the process of improving students' English learning and the level of college English teaching. Under the network environment, teachers can make full use of information technology to constantly broaden the scope of study. Among which guiding students to correctly choose the appropriate listening materials by applying multimedia technology; Timely and accurately grasping the progress of the students' ability in English listening; letting the students use Internet to do a good job of preparation before class, and finding related listening materials are all beneficial to the students' mutual discussion and communication in the class. Developing students' interest in English and cultivating autonomous learning consciousness plays a very important role in improving English ability.

3.2 Change Teaching Design method, Pay Attention to Students' Autonomous Learning Ability

Students who are the main body in the process of learning should have the ability of active learning. Developing the students' ability of autonomous learning mainly is to have the students analyze and think independently in the process of learning, and eventually achieve the goal of English teaching by gradually improving students' English learning consciousness. In modern English learning process, if one can carry out group learning plans alone and be able to accurately evaluate himself ,he is a completely autonomous learner. At the same time, teaching methods are rich and various with the rapid development of network information which make English class teaching design become more diversified, thus realize the integration of English teaching, increase the chances of the interaction between students and teachers, improve the students' participation, and eventually improve the efficiency of English teaching. Before English listening and speaking teaching, teachers let students preview relevant knowledge and vocabulary, and then let students carefully prepare a small essay related to the listening materials .So in the listening and speaking teaching process; teachers can let students address their small essays, providing students with an opportunity to "speak". So whether it is a listening and speaking material or a small essay, it can obtain good effect after discussion.

\subsection{Innovate Teaching Ideas, Improve the Teaching} Level

With continuous development of society, the traditional teaching concept has been unable to adapt to the needs of the development of modern society, therefore, reforming teaching is to renew the idea of teaching in the first place. Advanced teaching idea mainly requires teachers to change their roles from imparters of knowledge and teaching elites into students' learning guides. In the process of English listening and teaching, teachers' main duty is to inspire and mobilize students' interest in learning English and enable students to actively explore the problems in the process of English learning. Under the network environment, the advantage of college English listening and speaking teaching mode lies mainly in providing an autonomous 
learning environment for students, and maximally broaden the scope of students' autonomous learning to form the effective situation of teaching and learning interaction. In such cases, college English teachers should constantly change their teaching ideas; give full play to the advantages of English listening teaching under the network environment. In order to be able to innovate teaching concept, which college English teaching is required to have strong professional knowledge and study English. When various problems appear in the class, teachers should actively deal with unexpected problems. By using this method of changing teaching concept, students' English comprehensive ability can be effectively improved.

College English teachers must have accurate knowledge of the language, and the ability to speak English proficiently; teachers must always pay close attention to scientific and effective teaching theory in their teaching and research. before class, in the process of preparing lessons before teaching, college English teacher should focus on the application of materials within the knowledge as well as the expansion of English culture knowledge by adopting effective teaching approach to effectively stimulate students' interest in English- learning according to the actual situation of students. Certainly, in good teaching process, teachers need to propose problems which require some kind of creativeness and challenge so as to excavate students' demand on English knowledge.

\section{How to Make Use of Multimedia Network Resources to Improve the Overall Listening and Speaking Teaching Effect}

Under the background of rapid development in information technology and network application scope expanding gradually, students should learn to initiatively understand the characteristics and application method of the related English learning software, accurately grasp the network information technology, initiatively obtain the materials and information needed in the English learning so as to achieve the goal of college English teaching. Students should also formulate scientific and reasonable study plans according to their own actual situations, and find the most suitable listening materials through constantly self-evaluation, to eventually improve the goal of college English listening and speaking teaching.

Teachers should make full use of multimedia equipment based on the actual level of the students and courseware in the role strengthening the training of students' listening and speaking. In the multimedia courseware, teachers can establish the hierarchical learning plan and practice, enabling the student to select suitable training content according to their own actual situation. Teachers should help students to maximize the realization of personalized learning in the leading role of the teacher, making every student to become the protagonist of the classroom in order to "teach students in accordance with their aptitude".

English listening and speaking are complementary indivisible unity in the course of English learning. Meanwhile, oral English which is not standard will directly affect the effect of hearing, and bad hearing training will affect the oral English pronunciation and intonation. Therefore, teachers should encourage students to imitate the standard pronunciation actively, which is the basic step of teaching listening and speaking. Through strengthening students' listening training by use of the multimedia with a large amount of pronunciation training at the same time so as to improve the students' ability of speaking.

\section{CONCLUSIONS}

With the continuous development of modern society, computer information technology-centered teaching mode is gradually formed, creating a fresh energy for the traditional college English teaching. Therefore, in the process of modern teaching and learning, it should make full use of the network teaching mode. Especially in the contemporary college students' English listening and speaking teaching process, teachers should constantly strengthen their own level of teaching, improve teaching ability, carry out teaching design scientifically and 
reasonably in order to stimulate students' interest in learning, achieving the purpose of improving the level of college English teaching.

\section{References}

[1]Bernard Sposky. Conditions for Second Language Learning[M]. Shanghai Foreign language Education Press, 2000.

[2]Benson, Phil. Teaching and Researching Autonomy in Language Learning. Beijing: Foreign Language Teaching and Research Press, 2005.

[3]Bibliographies: Samour, L.A. and R.E Porter. Intercultural Communication: A Reader (5thed) [M].Wadsworth Publishing Co., 1988.

[4]Doye,C..Films for self-study [J]. Modern English Teacher, Vol,7. No. 4. 1998.

[5]Cook,Vivian. (1991,1996) Second Language Learning and Language Teaching. Beijing: Foreign Language and Research Press, 2000.

[6]Brown, H, D. (1994a). Principles of Language Learning and Teaching . NewYork: Prentice Hall. 